\title{
The Effect of Professionalism, Leadership Style, Organizational Commitment and Locus of Control on Auditor Performance (Study at a Public Accounting Firm in Jakarta)
}

\author{
Jemmy Esrom Serang ${ }^{1}$ and Wiwik Utami ${ }^{2}$ \\ Post Graduate Scholar ${ }^{1}$ and Lecturer ${ }^{2}$ \\ ${ }^{1}$ Master of Accounting Program \\ ${ }^{2}$ Lecturer in Postgraduate Program \\ Universitas Mercu Buana \\ Jakarta, Indonesia
}

\begin{abstract}
The purpose of this study was to analyze the influence of professionalism, leadership style, organizational commitment and locus of control on the performance of auditors of public accounting firms in Jakarta Province. The population sampling technique is purposive sampling. Samples are the auditors who participate in the survey; 74 respondents in 15 public accounting firms. Hypothesis test on this research is based on the multiple regression analysis. Based on the result, it was concluded that the professionalism and leadership style partially had a significant positive effect on auditor performance. Organizational commitment and locus of control partially had no significant effect on the auditor's performance. Professionalism, leadership style, organizational commitment and locus of control similarly had a significant positive effect on auditor performance.
\end{abstract}

Keywords: Professionalism, Leadership Style, Organizational Commitment, Locus Of Control, Auditor Performance

\section{INTRODUCTION}

The obligation of a professional auditor is to carry out his duties with sincerity and care, as a professional, the auditor should avoid being dishonest and negligent (Friska, 2012). Siahaan (2010) presents the results namely, professionalism influences auditor performance. Putri (2013) suggested that there is a positive effect of professionalism on auditor performance. Different from the results of research Cahyasumirat (2006) which states that professionalism has no effect on auditor performance. To support the success in carrying out its duties and functions properly, it is necessary to have good and qualified auditor performance. The term performance is often used in mentioning the achievement or level of success of individuals or groups of individuals. Human resources in a KAP is one of the most important aspects in an organization, so it can be said that KAP performance is very determined from the performance of its auditor. The form of work carried out by an auditor in achieving better work results or towards the achievement of organizational goals is an understanding of the auditor's performance (Trisnawati, 2014).

Siagian (2010) states that good leadership is a leader who can influence, inform, make decisions, and provide motivation aimed at improving organizations and employees. This opinion reflects the great role of leadership in an organization, so that a leader is expected to have the ability to motivate, direct, influence and communicate with his subordinates. The results of research from Mariam (2009) prove that there is a direct influence between leadership style and employee performance. This gives an indication that the leadership style of a leader influences the performance of his subordinates, besides that to get good performance and can be increased also requires the provision of learning to his subordinates. Sanjiwani (2016) proves that the Leadership Style has a positive effect on the auditor performance of the Public Accounting Firm (KAP). The better the way to lead a leader where the auditor works, the more influence the auditor's performance.

According to Sopiah (2008) states that organizational commitment is a psychological bond to employees characterized by strong trust and acceptance of the goals and values of the organization, willingness to work towards achieving organizational interests and the desire to maintain the position as members of the organization. 
Locus of control is one aspect of personality possessed by each individual and can be distinguished from internal locus of control and external locus of control (Sarita and Agustia, 2009: 3). Locus of Control refers to one's belief that what happens is because his control is internal or outside his control, namely external (Hirayappa, 2009). Locus of Control is the tendency of people to look for the cause of an event in a certain direction. Can be categorized into internal and external locus of control (Hanurawan, 2010). Whereas Locus of Control according to Ghufron \& Risnawita (2011) is a picture of a person's beliefs about the determinants of their behavior. Locus of Control is one of the factors that largely determine individual behavior. Research conducted by Made (2016) states that Locus of Control has a positive effect on the performance of auditors of Public Accounting Firms (KAP). The better the perspective of an auditor on an event the higher the performance will be. This happens because the locus of control plays a role in motivation and controlling stress. Individuals who have locus of control have higher satisfaction compared to individuals who do not have locus of control.

Based on differences in objects, research locations and existing GAP research, researchers are motivated to do the research again. Behavioral accounting research about the locus of control, leadership style and organizational commitment to performance in business companies has often been done, but for research on non-manufacturing business companies, such as KAP is still rarely done. Ayudiati (2010) who conducted research at the Bank of Central Java, Mariam (2010) with a sample of employee research at PT Asuransi. Differences in the location of previous studies by Sanjiwani (2016) conducted at the Bali Public Accounting Firm. The research to be written tries to use respondents that are different from previous studies, namely using auditor respondents who work at KAP in DKI Jakarta Province.

Based on the description above, this research is a development of several previous studies, which can then be formulated in the form of questions as follows: 1) Does professionalism affect auditor performance? ; 2) Does the leadership style affect the auditor's performance? ; 3) Does the organizational commitment affect the auditor's performance? ; 4) Does the locus of control affect the auditor's performance?

\section{LITERATURE REVIEW}

\subsection{Theory of Agency}

Ball, Robin, and Wu (2003) stated that the task of an agent as a company manager who knows more about internal information and company prospects in the future than the principal is to provide transparent disclosure of accounting information in the financial statements. The existence of an imbalance in the mastery of information in financial statements is referred to as information asymmetry.

\subsection{Theory of Motivation}

According to Robbins (2008), motivation is the willingness to spend a high level of effort for organizational goals which is conditioned by the ability of the effort to meet some individual needs.

\subsection{Professionalism}

According to Alvin A.Arens, Randal J. Elder, Mark S. Beasley was translated by Herman Wibowo (2008: 105) the definition of Auditor Professionalism, namely: "Auditor Professionalism is a responsibility to act more than just fulfilling one's own responsibilities as well as legal and regulatory provisions. society, public accountants as professionals acknowledge responsibility to the community, clients and fellow practitioners including respectable behavior even though it means self-sacrifice." Yudhi Herliansyah (2006), in the framework of meeting the requirements as a professional, the auditor must approve sufficient training. The training includes activities, such as seminars, symposia, training itself and other supporting activities. Through the training program the auditors also the socialization process can be adjusted to suit the changes to be encountered.

\subsection{Leadership Style}

According to Luthans (2002) the leadership style is a way for leaders to influence other people or subordinates in such a way that the person wants to do the will of the leader to achieve organizational goals even though personally it might not be liked. According to Siagian (2002) states that there are three types of leadership behaviors that are different among managers, namely: task oriented behavior (task oriented behavior), relationship oriented behavior (relationship oriented behavior), and participative leadership.

\subsection{Organizational Commitment}

Organizational Commitment according to Arfan Ikhsan (2010: 54) states that: "Organizational Commitment is the extent to which an employee takes sides with a particular organization and its objectives, when intending to maintain its membership in the organization". Understanding organizational commitment according to Sri Trisnaningsih (2007) is: "Organizational commitment 
is as a relative strength of the individual in identifying his involvement in the organization. This reflects the attitude of the individual will remain as a member of the organization shown by his hard work ."

\subsection{Locus Of Control}

According to Larsen and Buss (2002), defining locus of control is a concept that refers to an individual's beliefs about events that occur in his life. Locus of control describes how far a person views the relationship between the actions he does (actions) with the results / results (outcomes). According to Luthans (1995), states that work behavior can be explained by using locus of control, ie whether employees feel that their work results are controlled internally or externally. Employees who belong to the internal control group will feel that they can personally influence their performance through their abilities, expertise and efforts. Employees who belong to the external control group will feel that their performance is outside of their business, they feel that many external (external) factors affect their performance.

\subsection{Auditor's Performance}

According Mulyadi (2007: 337), states that: "Performance is the success of personnel, teams, or organizational units in realizing strategic goals that have been set previously with the expected behavior". According to the International of Organization (2002) defines that: "Auditors are people who have the competence to carry out audits". According to the Public Accounting Professional Standards (2011) states that: "The auditors conducted by the auditor can be qualified if they meet the requirements or auditing standards". Kalbers and Forgaty in Ichwan Maulana (2012) auditor performance as an evaluation of the work carried out by superiors, coworkers, self and direct subordinates. Performance (work performance) is a work that is achieved by someone in carrying out the work that is charged to him based on skill, experience and seriousness of time measured by considering quality, quantity and timeliness.

\subsection{Theoretical Framework}

Framework of thinking can be seen in Figure 2.1

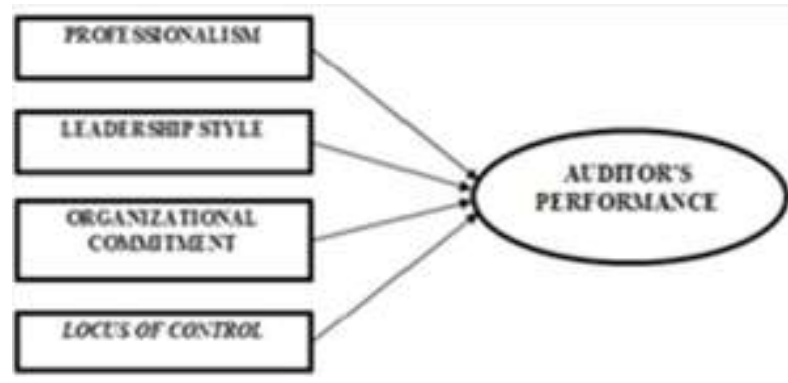

Figure 2.1 Model of Theoretical Framework

\section{RESEARCH METHODS}

The population in this study is 255 Public Accounting Firms (KAP) in the DKI Jakarta area registered at the Indonesian Institute of Certified Public Accountants (IAPI). Sampling uses a purposive sampling technique, which is a sampling method based on predetermined criteria. Data collection method used in this study is the method of observation with a questionnaire technique.

This study uses multiple linear regression analysis techniques tested with a significance level of 0.05 . Multiple linear regression analysis aims to obtain a picture of the effect of independent variables on the dependent variable. Before the multiple linear regression analysis is carried out first, testing the research instruments consisting of validity and reliability tests. After the research instrument test is fulfilled, a classic assumption test is performed which consists of a normality test, a multicollinearity test and a heteroscedasticity test. Based on the results of multiple linear regression analysis, the coefficient of determination test (R2) and the feasibility test of the model will be carried out using the F Test. In addition, the significance of the regression coefficient is also carried out using the t test.

The operational definition of the dependent variable in this study is the performance of the Auditor (Y), the performance of the auditor is the work achieved by someone in carrying out their duties in accordance with the responsibilities given to them, and is one of the benchmarks used to determine whether a job performed will good or vice versa (Kalbers and Fogarty, 1995 in Fanani et al, 2008). Auditor performance in this study adopted an instrument developed by Rizzo et al. (1970). The instrument consists of seven (7) question items.

Researchers used a scale of research with a range of scores $1-5$, respondents were asked to give a sign $(\sqrt{ })$ on alternative answers for each question, the level of scoring was done as follows; 1) $\mathrm{SD}=$ Strongly Disagree score 1 ; 2) $\mathrm{D}=\mathrm{Disagree}$ score 2 ; 3) $\mathrm{N}=$ Neutral 3; 4) $\mathrm{A}=$ Agree a score of 4; 5) $\mathrm{SA}=$ Strongly Agree a score of 5. 
This study uses multiple linear regression analysis techniques, but before testing the research instrument was conducted first to determine the sincerity of respondents in filling out the questionnaire. The validity of a research result is determined by the measuring instrument used and the data obtained (Sugiyono, 2013: 168).

Data analysis technique is a data processing technique that is collected and then interpreted the results of the analysis which are then used to answer the problems that have been formulated. The data analysis method used in solving the problem of this study is multiple linear regression analysis using the assumptions of classical assumptions to ensure that data is nominally distributed, and does not contain elements of autocorrelation, multicollinearity, heteroscedasticity. Based on the multiple linear regression analysis, the coefficient of determination testing (R2), the model suitability test (F test), and the individual significance test ( $\mathrm{t}$ test) were performed.

\section{RESULTS AND DISCUSSION}

Data collection is carried out by distributing research questionnaires directly to respondents by visiting a Public Accountant Office in the DKI Jakarta Region. The distribution was carried out from June to August 2019. Researchers distributed to 255 Public Accountant Offices and only 15 Public Accountant Offices received in the DKI Jakarta Region. The testing of the research instrument was carried out in advance to find out the seriousness of the respondents in filling out the questionnaire, which included validity testing and reliability testing.

\subsection{Descriptive statistics \\ 4.1.1 Professionalism $\left(\mathrm{X}_{1}\right)$}

Table 4.1 Descriptive Statistics Of Professionalism

\begin{tabular}{|c|c|c|c|c|c|c|c|}
\hline \multirow{2}{*}{ No } & \multirow{2}{*}{ QUESTION } & \multicolumn{5}{|c|}{ ANSWER } & \multirow[t]{2}{*}{ Mean } \\
\hline & & SD & D & $\mathbf{N}$ & A & SA & \\
\hline \multicolumn{8}{|c|}{ Pride of the Auditor } \\
\hline \multirow[t]{2}{*}{1.} & \multirow{2}{*}{$\begin{array}{l}I \text { am proud of the profession as an } \\
\text { maditor }\end{array}$} & 0 & 0 & 11 & 46 & 17 & \multirow{2}{*}{4,08} \\
\hline & & $0.0 \%$ & $0.0 \%$ & $14,9 \%$ & $62.2 \%$ & 23,096 & \\
\hline \multirow[t]{2}{*}{2} & \multirow{2}{*}{$\begin{array}{l}\text { The extermal auditor profession is } \\
\text { a profession that creates } \\
\text { transparency in society }\end{array}$} & 0 & 1 & 10 & 47 & 16 & \multirow{2}{*}{4,05} \\
\hline & & $0,0 \%$ & $1,4 \%$ & $13,5 \%$ & $63,5 \%$ & $21,6 \%$ & \\
\hline \multicolumn{8}{|c|}{ Auditor Participation } \\
\hline \multirow[t]{2}{*}{ I. } & \multirow{2}{*}{$\begin{array}{l}\text { I always come and participate in } \\
\text { extermal auditor professional } \\
\text { association meetings }\end{array}$} & 0 & 0 & 18 & 43 & 13 & \multirow{2}{*}{3,93} \\
\hline & & $0,0 \%$ & $0 \%$ & $24,3 \%$ & $58,1 \%$ & $17,6 \%$ & \\
\hline \multirow[t]{2}{*}{2} & \multirow{2}{*}{$\begin{array}{l}\text { I often exchange ideas with other } \\
\text { external auditors to improve my } \\
\text { skills and knowledge }\end{array}$} & 0 & 0 & 14 & 46 & 14 & \multirow{2}{*}{4,00} \\
\hline & & $0,0 \%$ & $0.0 \%$ & $18,9 \%$ & $62,2 \%$ & $18,9 \%$ & \\
\hline \multicolumn{8}{|c|}{ Auditor Ability } \\
\hline \multirow[t]{2}{*}{1.} & \multirow{2}{*}{$\begin{array}{l}\text { I carry out auditing dubes in } \\
\text { accordance with the knowledge } \\
\text { possessed. }\end{array}$} & 0 & 2 & 16 & 41 & 15 & \multirow[b]{2}{*}{3,93} \\
\hline & & $0,0 \%$ & 2,796 & $21,6 \%$ & $55,4 \%$ & $20,3 \%$ & \\
\hline \multirow[t]{2}{*}{2.} & \multirow{2}{*}{$\begin{array}{l}\text { I will stick to the profession as an } \\
\text { auditor even though I get other } \\
\text { job offers in return for more }\end{array}$} & 0 & 2 & 19 & 34 & 19 & \multirow{2}{*}{3,95} \\
\hline & & $0,0 \%$ & $2,7 \%$ & $25.7 \%$ & $45,9 \%$ & $25,7 \%$ & \\
\hline \multirow[t]{2}{*}{3.} & \multirow{2}{*}{$\begin{array}{l}\text { Extermal auditors have a reliable } \\
\text { way to see the competence of } \\
\text { other external auditors }\end{array}$} & 0 & 0 & 13 & 4 I & 20 & \multirow[b]{2}{*}{4,09} \\
\hline & & $0,0 \%$ & $0,0 \%$ & $17.6 \%$ & $55,4 \%$ & $27,0 \%$ & \\
\hline \multirow[t]{2}{*}{4.} & \multirow{2}{*}{$\begin{array}{l}\text { In expressing my opinion on the } \\
\text { financial statements, I was not } \\
\text { under management pressure }\end{array}$} & 0 & 2 & 11 & 43 & 18 & \multirow[b]{2}{*}{4,04} \\
\hline & & $0,0 \%$ & $2,7 \%$ & $14,9 \%$ & $58,1 \%$ & $24,3 \%$ & \\
\hline \multirow[t]{2}{*}{5.} & I plan and decide the results of & 0 & 2 & 17 & 41 & 14 & \\
\hline & $\begin{array}{l}\text { my audit based on the facts that } 1 \\
\text { encountered in the examination } \\
\text { process }\end{array}$ & $0.0 \%$ & $2.7 \%$ & $23,0 \%$ & $55.4 \% 6$ & $18,9 \%$ & 3,91 \\
\hline 6. & I find it too risky to leave work & 2 & 4 & 14 & 32 & 22 & $=92$ \\
\hline & that hasn't been completed & $2,7 \%$ & $3.4 \%$ & $18,9 \%$ & $43,2 \%$ & $29.7 \%$ & 3,92 \\
\hline & Mean & & & & 99 & & \\
\hline
\end{tabular}

The statistical results obtained that the average (mean) Professionalism of 3.99. And the highest mean in the Professionalism auditor's dimension is obtained in question no. 1, that I am proud of the profession as an auditor, this means that the auditors are happy and proud of the position and work being carried out, with the acquisition of a mean of 4.08. In the dimension of auditor participation the highest mean is obtained in question no. 4, which is that auditors often exchange ideas with other external auditors to improve the auditor's skills and knowledge. It can be concluded that the auditors in carrying out the auditing process always discuss with other auditor colleagues in order to add skills and insight in taking audit opinions, with the acquisition of a mean of 4.00. In the dimension of the highest mean auditor's ability obtained in question no. 7, External auditors have a reliable way of looking at other external auditors' competencies, this can be concluded that the auditors know each other's abilities of other external auditor colleagues, with a mean acquisition of $4,09$.

\subsubsection{Leadership Style $\left(X_{2}\right)$}

The statistical results obtained that the average (mean) Leadership Style of 3.95. And the highest mean in the dimension of auditor relationship is obtained in question no. 5: The relationship between members of the organization where I work is always good and harmonious, this means that the auditors must create a good relationship between fellow auditors well, with a mean acquisition of 4.11. In the dimension of auditor communication the highest mean is obtained in question No. 6 namely Communication between 
superiors, subordinates, and coworkers is very open and pleasant. It can be concluded that the auditors in carrying out the auditing process always discuss with superiors and other auditors in order to add a harmonious working atmosphere, with the acquisition of a mean of 4.09 .

Table 4.2 Descriptive Statistics Of Leadership Style

\begin{tabular}{|c|c|c|c|c|c|c|c|}
\hline \multirow{2}{*}{ No } & \multirow{2}{*}{ QUESTION } & \multicolumn{5}{|c|}{ ANSWER } & \multirow[t]{2}{*}{ Mean } \\
\hline & & SD & D & $\mathbf{N}$ & A & SA & \\
\hline \multicolumn{8}{|c|}{ Auditor Relations } \\
\hline \multirow[t]{2}{*}{1.} & \multirow{2}{*}{$\begin{array}{l}\text { The relationship between superiors and } \\
\text { subordinates where I work is very } \\
\text { close }\end{array}$} & 1 & 2 & 29 & 30 & 12 & \multirow{2}{*}{3,68} \\
\hline & & $1,4 \%$ & $2,7 \%$ & $39,2 \%$ & $40,5 \%$ & $16,2 \%$ & \\
\hline \multirow[t]{2}{*}{2.} & \multirow{2}{*}{$\begin{array}{l}\text { There is mutual trust between } \\
\text { superiors, subordinates and colleagues } \\
\text { in the profession }\end{array}$} & 0 & 1 & 10 & 53 & 10 & \multirow[b]{2}{*}{3,97} \\
\hline & & $0,0 \%$ & $1,4 \%$ & $13,5 \%$ & $71,6 \%$ & $13,5 \%$ & \\
\hline \multirow[t]{2}{*}{3.} & \multirow{2}{*}{$\begin{array}{l}\text { There is a family atmosphere where I } \\
\text { work }\end{array}$} & 0 & 0 & 10 & 56 & 8 & \multirow{2}{*}{3,97} \\
\hline & & $0,0 \%$ & $0,0 \%$ & $13,5 \%$ & $75,7 \%$ & $10,8 \%$ & \\
\hline \multirow[t]{2}{*}{4.} & \multirow{2}{*}{$\begin{array}{l}\text { The leaders at my place of work really } \\
\text { appreciate the ideas of subordinates }\end{array}$} & 0 & 1 & 16 & 48 & 9 & \multirow{2}{*}{3,88} \\
\hline & & $0,0 \%$ & $1,4 \%$ & $21,6 \%$ & $64,9 \%$ & $12,2 \%$ & \\
\hline \multirow[t]{2}{*}{5.} & \multirow{2}{*}{$\begin{array}{l}\text { The relationship between members of } \\
\text { the organization where I work is } \\
\text { always good and harmonious }\end{array}$} & 0 & 0 & 6 & 54 & 14 & \multirow{2}{*}{4,11} \\
\hline & & $0,0 \%$ & $0,0 \%$ & $8,1 \%$ & $73,0 \%$ & $18,9 \%$ & \\
\hline \multicolumn{8}{|c|}{ Auditor communication } \\
\hline \multirow[t]{2}{*}{1.} & \multirow{2}{*}{$\begin{array}{l}\text { Communication between superiors, } \\
\text { subordinates, and cow orkers is very } \\
\text { open and pleasant }\end{array}$} & 0 & 0 & 5 & 57 & 12 & \multirow{2}{*}{4,09} \\
\hline & & $0,0 \%$ & $0,0 \%$ & $6,8 \%$ & $77,0 \%$ & $16,2 \%$ & \\
\hline \multirow[t]{2}{*}{2.} & \multirow{2}{*}{$\begin{array}{l}\text { The leadership in my place of work is } \\
\text { able to communicate with subordinates } \\
\text { clearly and effectively }\end{array}$} & 0 & 0 & 13 & 53 & 8 & \multirow{2}{*}{3,93} \\
\hline & & $0,0 \%$ & $0,0 \%$ & $17,6 \%$ & $71,6 \%$ & $10,8 \%$ & \\
\hline \multirow[t]{2}{*}{3.} & \multirow{2}{*}{$\begin{array}{l}\text { The leader at my place of work, } \\
\text { always gives direction in doing the } \\
\text { right task }\end{array}$} & 0 & 0 & 16 & 47 & 11 & \multirow[b]{2}{*}{3,93} \\
\hline & & $0,0 \%$ & $0,0 \%$ & $21,6 \%$ & $63,5 \%$ & $14,9 \%$ & \\
\hline \multirow[t]{3}{*}{4.} & \multirow{2}{*}{$\begin{array}{l}\text { The leadership at my place of work } \\
\text { always emphasizes work by focusing } \\
\text { on goals and results }\end{array}$} & 0 & 1 & 11 & 47 & 15 & \multirow[b]{2}{*}{4,03} \\
\hline & & $0,0 \%$ & $1,4 \%$ & $14,9 \%$ & $63.5 \%$ & $20,3 \%$ & \\
\hline & Mean & & & & & & \\
\hline
\end{tabular}

\subsubsection{Organizational Commitment $\left(\mathrm{X}_{3}\right)$}

Table 4.3 Descriptive Statistics Of Organizational Commitment

\begin{tabular}{|c|c|c|c|c|c|c|c|}
\hline \multirow{2}{*}{ No } & \multirow{2}{*}{ QUESTION } & \multicolumn{5}{|c|}{ ANSWER } & \multirow[t]{2}{*}{ Mean } \\
\hline & & SD & D & $\mathbf{N}$ & A & SA & \\
\hline \multicolumn{8}{|c|}{ Audience Ownership } \\
\hline \multirow[t]{2}{*}{1.} & \multirow{2}{*}{$\begin{array}{l}\text { I feel I have an organization where I } \\
\text { work }\end{array}$} & 0 & 0 & 6 & 48 & 20 & \multirow{2}{*}{4,19} \\
\hline & & $0,0 \%$ & $0,0 \%$ & $8,1 \%$ & $64,9 \%$ & $27,0 \%$ & \\
\hline \multirow[t]{2}{*}{2.} & \multirow{2}{*}{$\begin{array}{l}\text { I feel emotionally attached to the } \\
\text { organization where I work }\end{array}$} & 0 & 2 & 20 & 35 & 17 & \multirow{2}{*}{3,91} \\
\hline & & $0,0 \%$ & $2,7 \%$ & $27,0 \%$ & $47,3 \%$ & $23,0 \%$ & \\
\hline \multirow[t]{2}{*}{3.} & \multirow{2}{*}{$\begin{array}{l}\text { I feel part of an organization where I } \\
\text { work. }\end{array}$} & 0 & 0 & 3 & 46 & 25 & \multirow{2}{*}{4,30} \\
\hline & & $0,0 \%$ & $0,0 \%$ & $4,1 \%$ & $62,2 \%$ & $33,8 \%$ & \\
\hline \multirow[t]{2}{*}{4.} & \multirow{2}{*}{$\begin{array}{l}\text { I feel that the organizational problems } \\
\text { I work for are also my problems }\end{array}$} & 0 & 0 & 6 & 48 & 20 & \multirow{2}{*}{4,19} \\
\hline & & $0,0 \%$ & $0 \%$ & $8,1 \%$ & $64,9 \%$ & $27,0 \%$ & \\
\hline \multirow[t]{2}{*}{5.} & \multirow{2}{*}{$\begin{array}{l}\text { I currently remain in the company } \\
\text { because of the commitment to the } \\
\text { organization. }\end{array}$} & 0 & 1 & 22 & 37 & 14 & \multirow{2}{*}{3,86} \\
\hline & & $0,0 \%$ & $1,4 \%$ & $29,7 \%$ & $50,0 \%$ & $18,9 \%$ & \\
\hline \multirow[t]{2}{*}{6.} & \multirow{2}{*}{$\begin{array}{l}\text { The main reas on I keep working at } \\
\text { this company is because of loyalty to } \\
\text { the company. }\end{array}$} & 0 & 0 & 5 & 50 & 19 & \multirow{2}{*}{4,19} \\
\hline & & $0,0 \%$ & $0 \%$ & $6,8 \%$ & $67,6 \%$ & $25,7 \%$ & \\
\hline \multirow[t]{2}{*}{7.} & \multirow{2}{*}{$\begin{array}{l}\text { I feel no commitment if I leave the } \\
\text { organization where I work }\end{array}$} & 0 & 0 & 2 & 47 & 25 & \multirow{2}{*}{4,31} \\
\hline & & $0 \%$ & $0 \%$ & $2,7 \%$ & $63,5 \%$ & $33,8 \%$ & \\
\hline \multicolumn{8}{|c|}{ Organizational Impact for Auditors } \\
\hline \multirow[t]{2}{*}{ 1. } & \multirow{2}{*}{$\begin{array}{l}\text { The organization I work for means a } \\
\text { lot to me }\end{array}$} & 0 & 0 & 2 & 53 & 19 & \multirow{2}{*}{4,23} \\
\hline & & $0,0 \%$ & $0,0 \%$ & $2,7 \%$ & $71,6 \%$ & $25,7 \%$ & \\
\hline \multirow[t]{2}{*}{2.} & \multirow{2}{*}{$\begin{array}{l}\text { Ifind it hard to be attached to other } \\
\text { organizations like the organization } \\
\text { where I work. }\end{array}$} & 0 & 0 & 4 & 40 & 30 & \multirow{2}{*}{4,35} \\
\hline & & $0,0 \%$ & $0 \%$ & $5,4 \%$ & $54,1 \%$ & $40,5 \%$ & \\
\hline 3. & I want to try above the normal limits & 0 & 0 & 1 & 55 & 18 & \\
\hline & $\begin{array}{l}\text { for the success of the company where } \\
\text { I work }\end{array}$ & $0,0 \%$ & $0,0 \%$ & $1,4 \%$ & $74,3 \%$ & $24,3 \%$ & 4,23 \\
\hline & Mean & & & & 18 & & \\
\hline
\end{tabular}

The statistical results obtained that the mean (mean) Organizational Commitment of 4.18. And the highest mean on the auditor's sense of ownership dimension is obtained in question no. 7: I feel no commitment if I leave the organization where I work, this means that the auditors must form and build a strong commitment to the organization so that it is not easily influenced by the surrounding environment to move work, with a mean gain of 4.31. In the dimension of organizational impact for the auditor the highest mean is obtained in question no. 9, which is that I have difficulty engaging with other organizations such as the organization where I work. It can be concluded that the auditors in carrying out the auditing process always rely on the 
organization as the second house to discuss with superiors and other auditor colleagues in order to add a harmonious and familial working atmosphere, with a mean acquisition of 4.35 .

4.1.4 Locus of Control $\left(\mathrm{X}_{4}\right)$

Table 4.4 Descriptive Statistics Of Locus of Control

\begin{tabular}{|c|c|c|c|c|c|c|c|}
\hline \multirow{2}{*}{ No } & \multirow{2}{*}{ QUESTION } & \multicolumn{5}{|c|}{ ANSWER } & \multirow[t]{2}{*}{ Mean } \\
\hline & & SD & D & $\mathbf{N}$ & A & SA & \\
\hline \multicolumn{8}{|c|}{ Auditor's Note } \\
\hline \multirow[t]{2}{*}{1.} & \multirow{2}{*}{$\begin{array}{l}\text { I work with a list of notes I have } \\
\text { previously made }\end{array}$} & 0 & 0 & 17 & 54 & 3 & \multirow{2}{*}{3,81} \\
\hline & & $0,0 \%$ & $0,0 \%$ & $23,0 \%$ & $73,0 \%$ & $4,1 \%$ & \\
\hline \multicolumn{8}{|c|}{ Things That Affect the Auditor } \\
\hline \multirow[t]{2}{*}{2.} & \multirow{2}{*}{$\begin{array}{l}\text { I could not determine what would } \\
\text { happen to my life }\end{array}$} & 0 & 2 & 15 & 50 & 7 & \multirow{2}{*}{3,84} \\
\hline & & $0,0 \%$ & $2,7 \%$ & $20,3 \%$ & $67,6 \%$ & $9,5 \%$ & \\
\hline \multirow[t]{2}{*}{3.} & \multirow{2}{*}{$\begin{array}{l}\text { My falure happened because I was } \\
\text { not trying to achieve it }\end{array}$} & 0 & 0 & 15 & 49 & 10 & \multirow{2}{*}{3,93} \\
\hline & & $0,0 \%$ & $0,0 \%$ & $20,3 \%$ & $66,2 \%$ & $13,5 \%$ & \\
\hline \multirow[t]{2}{*}{4.} & \multirow{2}{*}{$\begin{array}{l}\text { My life is determined by my own } \\
\text { actions }\end{array}$} & 0 & 2 & 29 & 41 & 2 & \multirow{2}{*}{3,58} \\
\hline & & $0,0 \%$ & $2,7 \%$ & $39,2 \%$ & $55,4 \%$ & $2,7 \%$ & \\
\hline \multirow[t]{2}{*}{5.} & \multirow{2}{*}{ My efforts did not produce results } & 0 & 0 & 23 & 48 & 4 & \multirow{2}{*}{3,73} \\
\hline & & $0,0 \%$ & $0,0 \%$ & $31,1 \%$ & $64,9 \%$ & $4,1 \%$ & \\
\hline \multirow[t]{3}{*}{6.} & \multirow{2}{*}{$\begin{array}{l}\text { I have little influence on success in } \\
\text { my own work }\end{array}$} & 0 & 0 & 14 & 59 & 1 & \multirow{2}{*}{3,82} \\
\hline & & $0,0 \%$ & $0,0 \%$ & $18,9 \%$ & $79,7 \%$ & $1,4 \%$ & \\
\hline & Mean & & & & 79 & & \\
\hline
\end{tabular}

The statistical results obtained that the mean (mean) of Locus of Control was 3.79. And the highest mean in the dimensions of the auditor's notes is obtained in question no. 1: I work with a list of notes that I have previously made, this means that the auditors work according to personal records and mechanisms that have been determined, with a mean acquisition of 3.81 . On the dimension of the thing that affects the auditor the highest mean is obtained in question no. 3, which is my failure that occurs because I did not try to achieve it. a mean of 3.93 .

\subsubsection{Auditor Performance (Y)}

Table 4.5 Descriptive Statistics Of Auditor Performance

\begin{tabular}{|c|c|c|c|c|c|c|c|}
\hline \multirow{2}{*}{ No } & \multirow{2}{*}{ QUESTION } & \multicolumn{5}{|c|}{ ANSWER } & \multirow[t]{2}{*}{ Mean } \\
\hline & & SD & D & $\mathbf{N}$ & $A$ & SA & \\
\hline \multicolumn{8}{|c|}{ Problem solving } \\
\hline \multirow[t]{2}{*}{1.} & \multirow{2}{*}{$\begin{array}{l}\text { I was able to complete more work in a } \\
\text { certain period of time compared to my } \\
\text { other colleagues }\end{array}$} & 0 & 0 & 18 & 46 & 10 & \multirow[b]{2}{*}{3,89} \\
\hline & & $0,0 \%$ & $0,0 \%$ & $24,3 \%$ & $62,2 \%$ & $13,5 \%$ & \\
\hline \multirow[t]{2}{*}{2.} & \multirow{2}{*}{$\begin{array}{l}\text { I found a way to improve audit } \\
\text { procedures }\end{array}$} & 0 & 0 & 22 & 44 & 8 & \multirow{2}{*}{3,81} \\
\hline & & $0,0 \%$ & $0,0 \%$ & $29,7 \%$ & $59,5 \%$ & $10,8 \%$ & \\
\hline \multirow[t]{2}{*}{3.} & \multirow{2}{*}{$\begin{array}{l}\text { I rated my performance the highest } \\
\text { compared to other auditors who were } \\
\text { at my level }\end{array}$} & 0 & 0 & 26 & 36 & 12 & \multirow[b]{2}{*}{3,81} \\
\hline & & $0,0 \%$ & $0 \%$ & $35,1 \%$ & $48,6 \%$ & $16,2 \%$ & \\
\hline \multirow[t]{2}{*}{4.} & \multirow{2}{*}{$\begin{array}{l}\text { The results of my work cause me to be } \\
\text { valued by my friends }\end{array}$} & 0 & 0 & 22 & 34 & 18 & \multirow{2}{*}{3,95} \\
\hline & & $0,0 \%$ & $0 \%$ & $29,7 \%$ & $45,9 \%$ & $24,3 \%$ & \\
\hline \multicolumn{8}{|c|}{ Auditor's Solution } \\
\hline \multirow[t]{2}{*}{1.} & \multirow{2}{*}{$\begin{array}{l}\text { I always give constructive suggestions } \\
\text { to supervisors about how audit work } \\
\text { should be done }\end{array}$} & 0 & 1 & 18 & 46 & 9 & \multirow{2}{*}{3,85} \\
\hline & & $0,0 \%$ & $1,4 \%$ & $24,3 \%$ & $62,2 \%$ & $12,2 \%$ & \\
\hline \multirow[t]{2}{*}{2.} & \multirow{2}{*}{$\begin{array}{l}\text { The results of my work are always } \\
\text { considered very good }\end{array}$} & 0 & 1 & 12 & 47 & 14 & \multirow{2}{*}{4,00} \\
\hline & & $0,0 \%$ & $1,4 \%$ & $16,2 \%$ & $63,5 \%$ & $18,9 \%$ & \\
\hline \multicolumn{8}{|c|}{ Auditor Relationship with Clients } \\
\hline \multirow[t]{3}{*}{1.} & Maintaining and improving & 0 & 0 & 18 & 45 & 11 & \multirow{2}{*}{3,91} \\
\hline & $\begin{array}{l}\text { relationships with clients is an } \\
\text { important part of my job }\end{array}$ & $0,0 \%$ & $0,0 \%$ & $24,3 \%$ & $60,8 \%$ & $14,9 \%$ & \\
\hline & Mean & & & & 39 & & \\
\hline
\end{tabular}

The statistical results obtained that the average (mean) of Auditor Performance of 3.89. And the highest mean in the dimension of problem solving is obtained in question no. 4: The results of my work cause me to be valued by my friends, this means that the auditors must find a good solution in carrying out audit procedures and naturally will make themselves valued in an organizational environment. , with a mean acquisition of 3.95. In the dimension of the highest mean auditor solution obtained in question no. 6: My work results are always considered very good, it can be concluded that the auditors in carrying out the auditing process always discuss and provide ideas and proposals to superiors in order to add skills in taking audit opinions so that the results of their work got good grades, with a mean acquisition of 4.00. In the dimension of auditor relationship with client the highest mean is obtained 
in question no. 7 namely maintaining and improving relations with clients is an important part of my work, it can be concluded that auditors must maintain relationships with clients to access all information related to audit activities and complete audit work well, with the acquisition of a mean of 3.91 .

\subsection{Data Quality Test Results}

\subsubsection{Reliability Test}

Table 4.6 Reliability Test

\begin{tabular}{|c|c|c|}
\hline Variabel & Cronbach's Alpha & Keterangan \\
\hline Profesionalisme & .956 & Reliabel \\
\hline Gaya Kepemimpinan & .841 & Reliabel \\
\hline Komitmen Organisasi & .856 & Reliabel \\
\hline Locus Of Control & .728 & Reliabel \\
\hline Kinerja Auditor & .818 & Reliabel \\
\hline
\end{tabular}

Each question item used will be able to obtain consistent data which means that if the statement is filed again, an answer will be obtained that is relatively the same as the previous answer.

\subsection{Classic Assumption Test Results}

\subsubsection{Mutlikolonieritas Test}

Table 4.7 Mutlikolonieritas Test

\begin{tabular}{|c|c|c|c|c|c|c|c|}
\hline \multicolumn{8}{|l|}{ Coefficients" } \\
\hline \multirow[t]{2}{*}{ Model } & \multicolumn{2}{|c|}{$\begin{array}{l}\text { Unstandardized } \\
\text { Coefficients }\end{array}$} & \multirow{2}{*}{$\begin{array}{l}\text { Standardi } \\
\text { zed } \\
\text { Coefficie } \\
\text { nts } \\
\text { Beta }\end{array}$} & \multirow[t]{2}{*}{$t$} & \multirow[t]{2}{*}{ Sig. } & \multicolumn{2}{|c|}{ Collinearity Statistics } \\
\hline & $\mathbf{B}$ & $\begin{array}{l}\text { Std. } \\
\text { Error }\end{array}$ & & & & Tolerance & VIF \\
\hline (Constant) & -.059 & 857 & &,- 068 & .946 & & \\
\hline Protesionalisme & 211 & 100 & 285 & 2.111 & .038 & 530 & 1.885 \\
\hline $\begin{array}{l}\text { gaya } \\
\text { kepemimpinan }\end{array}$ & 337 & 121 & 295 & 2,778 & .007 & 855 & 1,169 \\
\hline $\begin{array}{l}\text { komitmen } \\
\text { organisasi }\end{array}$ & 249 & .152 & 214 & 1,641 & .105 & 569 & 1.757 \\
\hline locus of control & 193 & 133 & 152 & 1.456 & 150 & .889 & 1,126 \\
\hline
\end{tabular}

Variables Professionalism, leadership style, organizational commitment and locus of control are not multicolonieritas.

\subsubsection{Heteroscedasticity Test}

Table 4.8 Heteroscedasticity Test

\begin{tabular}{|c|c|c|c|c|c|c|}
\hline \multicolumn{7}{|c|}{ Coefficients* } \\
\hline \multicolumn{2}{|c|}{ Model } & \multicolumn{2}{|c|}{ Unstandardced Coefficients } & \multirow{2}{*}{$\begin{array}{l}\text { Standardbed } \\
\text { Coefficients } \\
\text { Beta }\end{array}$} & \multirow[t]{2}{*}{$t$} & \multirow[t]{2}{*}{ Sig. } \\
\hline & & B & Std. Error & & & \\
\hline \multirow[t]{5}{*}{1} & (Constant) & 774 & 505 & & 1.532 & 130 \\
\hline & profesionalisme & 020 & 059 & 055 & 338 & 736 \\
\hline & $\begin{array}{l}\text { gaya } \\
\text { kepemimpinan }\end{array}$ & -.060 & .071 & -107 & -834 & .407 \\
\hline & $\begin{array}{l}\text { komitmen } \\
\text { organisasi }\end{array}$ & .020 &, 090 & .034 & .218 & .628 \\
\hline & locus of control & -.108 & .078 & -173 & $-1,377$ & 173 \\
\hline
\end{tabular}

It can be concluded that all variables do not occur heteroscedasticity because the significance value $>0.05$. 
International Journal of Advances in Scientific Research and Engineering (ijasre), Vol 6 (3), March -2020

4.3.3 Normality Test

Table 4.9 Normality Test

\begin{tabular}{|c|c|c|}
\hline \multicolumn{3}{|c|}{ One-Sample Kolmogorov-Smirnov Test } \\
\hline & & Unstandardized Residual \\
\hline \multicolumn{2}{|l|}{$\mathrm{N}$} & 74 \\
\hline \multirow[t]{2}{*}{ Normal Parameters* } & Mean & 0000000 \\
\hline & Std. Deviation & 36765135 \\
\hline \multirow[t]{3}{*}{ Most Extreme Differences } & Absolute & .045 \\
\hline & Positive & 046 \\
\hline & Negative &,- 040 \\
\hline \multicolumn{2}{|l|}{ Test Statistic } & .045 \\
\hline \multicolumn{2}{|l|}{ Asymp. Sig. (2-tailed) } & $200^{60}$ \\
\hline \multicolumn{3}{|l|}{ a. Test distribution is Normal. } \\
\hline \multicolumn{3}{|l|}{ b. Calculated from data. } \\
\hline \multicolumn{3}{|c|}{ c. Lilliefors Significance Correction. } \\
\hline \multicolumn{3}{|c|}{ d. This is a lower bound of the true signincance. } \\
\hline
\end{tabular}

The significance value (2-tailed) 0,200 is greater than 0.05 so that it can be concluded that the data used in this study are normally distributed.

4.4 Hypothesis Test Results

\subsubsection{Coefficient of determination}

Table 4.10 Coefficient of determination

\begin{tabular}{|c|c|c|c|c|}
\hline \multicolumn{5}{|c|}{ Model Summary } \\
\hline Model & $\mathbf{R}$ & R Square & Adjusted R Square & Std. Error of the Estimate \\
\hline 1 & $578^{\circ}$ & 336 & 296 & 378 \\
\hline \multicolumn{5}{|c|}{$\begin{array}{l}\text { a. Predictors (Constant), locus of control, profesionalisme, gaya kepemimpinan, } \\
\text { komitmen organisasi }\end{array}$} \\
\hline \multicolumn{5}{|c|}{ b. Dependent Variable: kinerja audtor } \\
\hline
\end{tabular}

The value of the correlation coefficient of 0.578 . The coefficient of determination is 0.335 or $33.5 \%$. From these calculations it can be seen that the influence of Professionalism, Leadership Style, Organizational Commitment, and Locus of Control on Auditor Performance by $33.5 \%$. While the remaining $65.5 \%$ is influenced by other variables outside the regression equation or variables not examined.

\subsubsection{Test Results F}

Table 4.11 Test Results F

\begin{tabular}{|c|c|c|c|c|c|}
\hline \multicolumn{6}{|l|}{ ANOVA* } \\
\hline Model & Sum of Squares & df & Mean Square & $\mathrm{F}$ & Sig. \\
\hline 1 Regression & 4,960 & 4 & 1.240 & 8,671 & $.000^{\circ}$ \\
\hline Residual & 9,867 & 69 & .143 & & \\
\hline Total & 14,827 & 73 & & & \\
\hline \multicolumn{6}{|c|}{ a. Dependent Variable: kinerja auditor } \\
\hline $\begin{array}{l}\text { b. Predictors: (C } \\
\text { komitmen organ }\end{array}$ & art), locus of con & & al & & \\
\hline
\end{tabular}

From the ANOVA test, the significance value was 0,000. The significance value is smaller than 0.05 , it can be said that Professionalism, Leadership Style, Organizational Commitment, and Locus of Control together have a significant effect on Auditor Performance.

\subsubsection{Test Results $T$}

Table 4.12 Test Results T

\begin{tabular}{|c|c|c|c|c|c|c|}
\hline \multicolumn{7}{|c|}{ Coefficients ${ }^{2}$} \\
\hline & & \multirow{2}{*}{\multicolumn{2}{|c|}{$\begin{array}{c}\text { Unstandardized } \\
\text { Coefficients }\end{array}$}} & \multirow{3}{*}{\begin{tabular}{|c|}
$\begin{array}{c}\text { Standardized } \\
\text { Coefficients }\end{array}$ \\
Beta \\
\end{tabular}} & \multirow[b]{3}{*}{$t$} & \multirow[b]{3}{*}{ Sig. } \\
\hline & & & & & & \\
\hline \multicolumn{2}{|c|}{ Model } & B & Std. Error & & & \\
\hline \multirow[t]{5}{*}{1} & (Constant) & -.059 & .857 & &,- 068 & 946 \\
\hline & \begin{tabular}{|l} 
Profesionalisme \\
\end{tabular} & 211 & .100 & 285 & 2,111 & .038 \\
\hline & Gaya Kepemimpinan & 337 & .121 & .295 & 2,778 &, 007 \\
\hline & Komitmen Organisasi & 249 & .152 & 214 & 1,641 &, 105 \\
\hline & Locus Of Control & .193 & 133 & .152 & 1,456 & .150 \\
\hline
\end{tabular}


The greatest regression coefficient is in the leadership style variable which has a value of 0.337 . This means that a leader in a Public Accounting Firm is very influential on the auditor's performance. Good dynamics and good character and leaders who are not authoritarian will provide an opportunity for auditors to achieve maximum auditor performance.

The organizational commitment variable has the greatest regression coefficient after leadership style which has a value of 0.249 . This means that the auditor's commitment to the Public Accounting Firm is very influential on the auditor's performance.

On the other hand, the professionalism variable has a regression coefficient of 0.211 . This means, professionalism is a determinant of achieving good auditor performance. The coefficient of professionalism variables which include training, participation in seminars, exchanging ideas and discussing with fellow auditors strongly support the achievement of auditor performance.

\subsection{Discussion of Research Results}

\subsubsection{Effect of Professionalism on Auditor Performance}

The relationship between auditor professionalism and auditor performance is if an auditor has high professionalism, then his performance will improve. These conditions cause the auditor to be trusted and can be relied upon in carrying out his work.

Based on the research results the professionalism variable has a significant positive effect on auditor performance. The results of this study support previous research conducted by Kusnadi (2015), Prabayanthi (2018), Temaja (2016).

\subsubsection{Effect of Leadership Style on Auditor Performance}

A leader can do various ways in the activity of influencing and motivating subordinates or others to take actions that are always directed towards the achievement of organizational goals. If an auditor led by a leader who has a way to lead well, then subordinates will feel happy at work so that performance will improve.

Based on the research results the Leadership Style variable has a significant positive effect on auditor performance. The results of this study support previous research conducted by Sanjiwani (2016).

\subsubsection{Effect of Organizational Commitment on Auditor Performance}

Organizational Commitment Variable does not significantly influence auditor performance. This can happen because auditors only maintain their professional attitude in working to achieve a goal and for them the organization does not mean to be fully part of them, because at any time they can leave the organization without fear of losing financial benefits or not getting a job elsewhere. The results of this study support previous research conducted by Srimindarti (2015) that the commitment of an auditor does not make the auditor work better.

\subsubsection{Effect of Locus of Control on Auditor Performance}

The Locus of Control variable does not significantly influence auditor performance. This shows that the perception of their control over fate, self-confidence and their belief in self-success is not related to Auditor Performance. The results of this study support previous research conducted by Dali (2013) and Srimindarti (2015).

\section{CONCLUSION AND SUGGESTION}

\subsection{Conclusion}

Professionalism has a positive and significant effect on auditor performance. This proves that the higher the professionalism in the auditor at the Public Accounting Firm, the higher the Auditor's Performance.

Leadership Style has a positive and significant effect on Auditor Performance. This proves that the greater the influence of a Leadership Style that is democratic, open, and embraces all employees like family in a Public Accounting Firm, the higher the Auditor's Performance.

Organizational Commitment has insignificant effect on the Auditor's Performance because the answers are not consistent. This proves that the Organizational Commitment in an auditor does not reduce or increase the Auditor's Performance because at any time they can leave the organization without fear of losing financial benefits or not getting a job elsewhere.

Locus of Control has no significant effect on Auditor Performance. This proves that the Locus of Control in an auditor does not reduce or increase the Auditor's Performance. An auditor is influenced by fate.

\subsection{Suggestion}

Although there are many Public Accounting Firms in DKI Jakarta, but they are not homogeneous. Thus, for further research it is recommended to expand the sample so that this research is not only taken from the DKI Jakarta area alone so that it can obtain research results with a higher level of generalization and homogeneity.

For academics, it is expected that future research can consider variables that have no effect on this study such as commitment. Further research needs to be added to the method of direct interviews because there are inconsistent answers to each respondent in an effort to collect data, to get more accurate results from the respondents. 


\section{REFERENCES}

1. $\quad$ Abdulloh. 2006. Tesis :"pengaruh budaya organisasi, locus of control dan kepuasan kerja terhadap kinerja karyawan pada kantor pelayanan pajak Semarang barat”. Program Studi Magister Manajemen Universitas Diponegoro, Semarang.

2. Agoes Sukrisno. 2008. Auditing Pemeriksaan oleh Kantor Akuntan Publik Jilid satu. Jakarta: Lembaga Penerbit Fakultas Ekonomi Universitas Indonesia.

3. Febrianty. Pengaruh Profesionalisme Auditor Terhadap Pertimbangan Tingkat Materialitas Audit Atas Laporan Keuangan, Jurnal Ekonomi dan Informasi Akuntansi Vol 2, no.2. 2012.

4. Iriyadi dan Vannywati. 2011. "Pengaruh Profesionalisme Auditor dan Etika Profesi Auditor Terhadap Pertimbangan Tingkat Materialitas”. Jurnal Ilmiah Ranggagading, Volume. 11, no 2, Oktober.

5. Institut Akuntan Publik Indonesia. 2011. "Standar Profesional Akuntan Publik”. Per 31 Maret 2011, Penerbit Salemba Empat, Jakarta.

6. Agustina, Lidya. 2009. Pengaruh konflik peran, ketidakjelasan peran, dan kelebihan peran terhadap kepuasan kerja dan kinerja auditor. Jurnal Akuntansi: vol.1,No.1, halaman 40-69.

7. Arens, Alvin A \& Loebbecke, james K. 2010. Auditing, an integrated approach. Seventh edition. Upper Saddle River, New Jersey : prentice-hall, inc.

8. Imam Ghozali, 2011. Aplikasi Analisis Multivariate Dengan Program SPSS, Edisi Kelima, Penerbit Universitas Diponegoro, Bandung.

9. Mulyadi, 2009. Auditing, Buku Satu, Edisi Ke Enam, Salemba Empat, Jakarta.

10. Setiawan, Ivan Aris dan Imam Ghozali. 2006. Akuntansi Keperilakuan : Konsep dan Kajian Empiris Perilaku Akuntan, BPFE UNDIP, Semarang.

11. Trisnaningsih, S. 2007. Independensi Auditor dan Komitmen Organisasi Sebagai Mediasi Pengaruh Pemehaman Good Governance, Gaya Kepemimpinan dan Budaya Organisasi Terhadap Kinerja Auditor. Simposium Nasional Akuntansi $\mathrm{X}$, Makasar.

12. Viator, R. E. 2001. "The Association of Formal and Informal Public Accounting Mentoring with Role Stress and Related Job Outcomes”. Accounting, Organizations and Society, Vol. 26 No. I, pp. 73-93.

13. Utami, Wiwik. 2006. Analisis Determinan Audit Delay Kajian Empiris Di Bursa Efek Jakarta. BULLETIN Penelitian No.09 Tahun 2006.

14. Herliansyah, Yudhi. Pengaruh Pengalaman Auditor Terhadap Penggunaan Bukti Tidak Relevan Dalam Auditor Judgment, Simposium Nasional Akuntansi 9 Padang tahun 2006. 